\title{
Corporate Constructed and Dissent Enabling Public Spheres: Differentiating Dissensual from Consensual Corporate Social Responsibility
}

\author{
Glen Whelan
}

Received: 29 November 2011 / Accepted: 14 January 2013/Published online: 6 August 2013

(C) Springer Science+Business Media Dordrecht 2013

\begin{abstract}
I here distinguish dissensual from consensual corporate social responsibility (CSR) on the grounds that the former is more concerned to organize (or portray) corporate-civil society disagreement than it is corporatecivil society agreement. In doing so, I first conceive of consensual CSR, and identify a positive and negative view thereof. Second, I conceive of dissensual CSR, and suggest that it can be actualized through the construction of dissent enabling, rather than consent-oriented, public spheres. Following this, I describe four actor-centred institutional theories-i.e. a sociological, ethical, transformative and economic perspective, respectively-and suggest that an economic perspective is generally well suited to explaining CSR activities at the organizational level. Accordingly, I then use the economic perspective to analyse a dissent enabling public sphere that Shell has constructed, and within which Greenpeace participated. In particular, I explain Shell's employment of dissensual CSR in terms of their core business interests; and identify some potential implications thereof for Shell, Greenpeace, and society more generally. In concluding, I highlight a number of ways in which the present paper can inform future research on business and society interactions.
\end{abstract}

Keywords Actor-centred institutional theory . Corporate social responsibility - Consensus . Dissensus · Public sphere

\section{G. Whelan ( $\square)$}

International Centre for Corporate Social Responsibility (ICCSR), Nottingham University Business School, Jubilee Campus, Wollaton Road, Nottingham NG8 1BB, UK e-mail: glen.whelan@nottingham.ac.uk

\section{Introduction}

The idea that corporate social responsibility (CSR) policies and practices can be oriented towards the organization (and/or portrayal) of corporate-civil society discordance is yet to be acknowledged within the CSR literature. By and large, this conceptual 'silence', or oversight, seems due to the widespread assumption that CSR activities do or should relate to processes of discursive or reasoned accordance between corporations and civil society (and/or stakeholders). Furthermore, it is indicated, or revealed, by the fact that a considerable portion of the CSR literature seeks to conceive, explain and/or portray the same, or very similar, consent-oriented CSR practices, in either a positive or negative light.

Positive writings on consensual CSR, for example, tend to suggest that corporate-civil society engagement processes can help to democratically legitimate a corporation's activities so long as they are not 'corrupted' by strategic or instrumental considerations: e.g. the concern to maximize profits (e.g. Gilbert and Rasche 2007; Scherer and Palazzo 2007). Negative writings, on the other hand, tend to suggest that, whilst a functional consensus may emerge through corporate-civil society dialogue, it will in effect always be 'corrupted' by some sort of hegemonic and/or discursive 'violence' (e.g. Blowfield 2005; Prasad and Elmes 2005).

It is in looking beyond these well established and competing perspectives of consensual CSR then, that I here conceive of dissensual CSR: i.e. a form of CSR that is more concerned to organize (and/or portray) corporate-civil society dissensus than it is corporate-civil society consensus. Given the nature of my analysis, I emphasize that I only engage in descriptive-explanatory theorizing, and not normative-prescriptive theorizing, in the present context. Nevertheless, and given that I presume the minimal amount 
of civil and political liberties that make corporate-civil society consent or dissent possible, the argument I advance only really makes sense with regard to communities informed by a liberal-democratic "ethic" (Habermas 1995, pp. 112, 126), or within a "complex" liberal-democratic "strategical situation" (Foucault 1978, pp. 92-93).

I structure the paper as follows. First, I briefly discuss the consensual orientation of the CSR literature; detail a specific and positive perspective of consensual CSR that takes influence from Habermas's (1990) discourse ethics (e.g. Gilbert and Rasche 2007); and detail a multifaceted negative perspective of consensual CSR (e.g. Blowfield 2005) that takes influence from Gramsci's notion of hegemony (1971) and Foucault's notion of discourse (e.g. 1972). Furthermore, I suggest that the positive and negative perspectives can be non-normatively conceived as acquiesce-compromise and compromise-avoid strategies, respectively (Oliver 1991). Second, I conceive of dissensual CSR with regard to some posited benefits of dissensus more generally (e.g. Rescher 1993), and suggest that it can be conceived as a defy strategy (Oliver 1991). Additionally, I combine insights from Habermas (1989) and Foucault (1987), and highlight that dissensual CSR can be actualized through the construction of what I term dissent enabling public spheres.

Third, I differentiate four actor-centred, and overlapping, perspectives, on institutional theory: i.e. a sociological (e.g. Aguilera and Jackson 2010, p. 530), ethical (e.g. Habermas 1990), transformative (e.g. Foucault 1984a) and economic (e.g. Oliver 1991) perspective, respectively. Whilst recognizing that all four perspectives have their merit, I suggest the economic perspective is best suited to explaining CSR activities at the corporate level. Accordingly, I then use the economic perspective to analyze a dissent enabling public sphere that Shell has recently constructed, and within which Greenpeace participated. In particular, I explain Shell's employment of dissensual CSR in terms of their core business interests; and identify some of the potential implications thereof for Shell, Greenpeace, and society more generally. In concluding, I summarize the paper's main contributions, and highlight a number of ways in which they can inform future research on business and society interactions.

\section{Consensual Corporate Social Responsibility}

CSR is commonly portrayed as a concept and/or practice that, whilst subject to differing understandings, is ultimately based on an implicit and abstract agreement that it is concerned to theorize or organize the business-society interface (Gond and Moon 2011, pp. 16-21). More specifically, it has been suggested that the theory and practice of CSR is characterized by a general privileging of consent over dissent (Blowfield 2005, p. 181).

Evan and Freeman's (1988, p. 103) work on normative stakeholder theory for example, which suggests that management should not "give primacy to one stakeholder group over another", and that managers should keep "relationships among stakeholders in balance", is clearly informed by these broader consensual tendencies. So too is Donaldson and Dunfeee's (1994) work on integrative social contracts theory: which states that corporations are morally obliged to comply with those hypernorms (e.g. the right to privacy) that all (rational) individuals would consent to in reasonable circumstances.

As these brief remarks indicate, stakeholder theory and integrative social contracts theory, and the CSR literature more generally, are informed by a consensual orientation. Nevertheless, I suggest that it is the international accountability standards (e.g. Gilbert et al. 2011) and/or political corporate responsibility (e.g. Scherer and Palazzo 2007) literatures that most clearly emphasize the importance of corporate-civil society consensus. It is these writings that I specifically associate with the positive perspective of consensual CSR.

\section{The Positive Perspective of Consensual CSR}

The positive perspective of consensual CSR relates to at least two overlapping developments. First, it relates to the empirical emergence of multi-constituent (and often transnational) initiatives that develop standards that seek to make corporations more socially responsible, more environmentally responsible, and/or, more accountable to their stakeholders (e.g. Gilbert et al. 2011). The Forest Stewardship Council-which was "established in 1993 as a response to concerns over global deforestation", has a membership composed of non-government organizations (NGOs) (e.g. World Wildlife Fund) and businesses (e.g. Tetra Pak), and promotes itself as a "pioneer forum where the global consensus on responsible forest management convenes" (FSC)—provides a good example of what I mean in these regards.

Second, it relates to the belief that the moral legitimacy of corporate activities is largely dependent on their being consented to by their stakeholders, and/or, by global civil society more generally (e.g. Gilbert and Rasche 2007; Scherer and Palazzo 2011). Perhaps most notably, it is informed by a specific application of Habermas's (1990, p. 66) discourse principle: which states that "only those norms can claim to be valid that meet (or could meet) with the approval of all affected in their capacity as participants in a practical discourse".

As these two developments suggest, the positive perspective of consensual CSR emphasizes that, so long as 
multi-stakeholder initiatives are characterized by genuine moral discourse-and/or are not 'corrupted' by corporate power and/or strategic motivations (Gilbert and Rasche 2007, p. 208; Scherer and Palazzo 2007, p. 1110)—then they can enable stakeholders to meaningfully act upon their posited right to hold corporations to account for their various acts and (moral) omissions (e.g. Gilbert et al. 2011, p. 24). In short, they suggest that multi-constituent initiatives can better ensure that corporate policies and practices enjoy relatively widespread levels of democratic (and/or moral) legitimacy.

Whilst the literature on the positive perspective of consensual CSR has both a descriptive and normative dimension, it can be beneficially looked at in the former terms alone. In particular, I suggest that once its normative connotations are stripped away, this literature begins to look like an empirical illustration of two of the strategies that Oliver (1991) discusses in her paper on strategic responses to institutional pressures: i.e. acquiesce and compromise. In illustrating this point, I first note that Oliver (1991) completes the following tasks in her widely cited paper.

First, she identifies five types of institutional pressuresi.e. cause, constituents, content, control and context-that corporations can subsequently respond to. Importantly, and as Table 1 details, the pressure these antecedents place on a corporation can vary from low to high depending on context. Within the United Kingdom (UK) for example, a fast food MNC subject to pressure from animal rights activists would be subject to a low cause of social/moral legitimacy: for the need to respect animal rights is not a widespread ethical belief in the UK. On the other hand, if the same MNC was subject to pressure to respect human rightswhich is a widespread and deeply entrenched ethical belief in the UK-then it would be subject to a high cause of social/moral legitimacy.

Second, Oliver (1991) identifies five strategies of increasing pro-activeness that organizations can employ when confronted by institutional pressures: i.e. acquiesce, compromise, avoid, defy and manipulate. As Table 2 details, each of the five strategies is itself associable with various sub-tactics: e.g. compromise can be associated with the tactics of balance and pacify.

Third, Oliver (1991) predicts the likelihood of an organization employing a specific strategy given the pressures they face. Amongst other things then, she suggests that a corporation (e.g. McDonalds) is likely to employ more pro-active strategies (e.g. defy) when the 'content' of the pressure (e.g. animal rights) is of a low 'consistency' with their interests (e.g. selling meat products). On the other hand, she suggests that a corporation is likely to employ a more reactive strategy (e.g. acquiesce) when a pressure's 'cause' has high moral legitimacy (e.g. the need for pharmacies to sell safe products).
With the terminology so clarified, I now refer to two examples to justify my above made claim: i.e. that the literature on the positive perspective of consensual CSR often appears to describe, or advocate, a combination of Oliver's (1991) strategies of acquiesce and compromise. First, I highlight that Gilbert and Rasche (2007, pp. 197, 205) provide a clear example of what Oliver (1991, p. 153) terms a balancing tactic when they suggest that Social Accountability 8000 -i.e. a "social accountability standard for retailers, brand companies, suppliers, and other organizations to maintain decent working conditions throughout the supply chain on a global basis"- should initiate a "moral discourse [that] aims at balancing the interests of all, or at least the most concerned stakeholders, by achieving a mutual agreement on the guidelines included in SA 8000". And second, I note that Scherer and Palazzo (2011, p. 917) provide a similarly clear example of a compromise strategy when they note that the Forest Stewardship Council has "established an internal governance structure that tries to balance the interest of economic actors, NGOs representing social interests, and NGOs representing environmental issues..." In short-and given that writings on the positive perspective of consensual CSR also talk of the need for MNCs to conform to consensual and/or participatory ideals more generally (e.g. Scherer and Palazzo 2011) - I suggest that the activities discussed within the positive perspective of consensual CSR literature, can be broadly conceived in terms of an acquiesce-compromise strategy.

\section{The Negative Perspective of Consensual CSR}

Whilst the broad literature on CSR is marked by a general tendency to privilege and promote the merits of consensus, there are dissenting voices. In particular, there is a selfconsciously 'critical' (e.g. Blowfield 2005; Levy 2008; Prasad and Elmes 2005) body of work that I here term the negative perspective of consensual CSR. It differs from the positive perspective in at least two ways.

First, and whereas the positive perspective suggests that corporations will sometimes privilege moral considerations when involved in the above-described multi-stakeholder initiatives, the negative perspective suggests that corporations will only ever engage in such initiatives for profitfocused reasons (Blowfield 2005, p. 181). More specifically-and whereas the positive perspective portrays corporate involvement in multi-stakeholder initiatives as being consistent with Oliver's (1991) acquiesce and compromise strategies-the negative perspective portrays such involvement in terms of her compromise and avoid strategies.

Second, and whereas the positive view is influenced by the work of Habermas, the negative view is influenced by the likes of Gramsci (1971) and Foucault (e.g. 1972). With 
Table 1 Institutional antecedents

\begin{tabular}{|c|c|}
\hline Institutional factor & $\begin{array}{l}\text { Description of institutional factor/illustration of low-high factor within a } \\
\text { contemporary western democracy (e.g. UK) }\end{array}$ \\
\hline \multicolumn{2}{|l|}{ Cause } \\
\hline Social/Moral & $\begin{array}{l}\text { Description: Degree to which factor complies with widespread ethical, moral } \\
\text { or social norms }\end{array}$ \\
\hline Legitimacy & $\begin{array}{l}\text { Low: Animal rights (as 'equal' respect for animal and human life) } \\
\text { High: Human rights }\end{array}$ \\
\hline Economic efficiency & $\begin{array}{l}\text { Description: Degree to which factor is consistent with corporation's } \\
\text { economic interests } \\
\text { Low: Craft techniques from the middle ages } \\
\text { High: Energy (and hence cost) saving initiatives }\end{array}$ \\
\hline \multicolumn{2}{|l|}{ Constituents } \\
\hline Multiplicity & $\begin{array}{l}\text { Description: Degree of multiplicity (versus univocity) amongst constituents } \\
\text { regarding factor } \\
\text { Low: Need for religious toleration } \\
\text { High: Best means by which to solve climate change }\end{array}$ \\
\hline Dependence & $\begin{array}{l}\text { Description: Degree to which corporation is dependent on constituents } \\
\text { Low: Fringe social movements with limited power } \\
\text { High: Mainstream consumers and capital providers }\end{array}$ \\
\hline \multicolumn{2}{|l|}{ Content } \\
\hline Consistency & $\begin{array}{l}\text { Description: Degree to which norms or requirements are consistent with } \\
\text { corporate interests (e.g. the interests of an alcohol company) } \\
\text { Low: Raising the minimum drinking age from } 18 \text { to } 25 \\
\text { High: Concern to promote pubs and drinking as a part of British culture }\end{array}$ \\
\hline Constraint & $\begin{array}{l}\text { Description: Degree to which norm diminishes corporate voluntarism } \\
\text { Low: Standards encouraging corporations to promote a healthy lifestyle } \\
\text { amongst employees } \\
\text { High: Standards requiring corporations to provide employees with access to } \\
\text { diet and exercise professionals }\end{array}$ \\
\hline \multicolumn{2}{|l|}{ Control } \\
\hline Coercion & $\begin{array}{l}\text { Description: Degree to which factor is legalized/enforced } \\
\text { Low: Drug testing amongst hospitality professionals } \\
\text { High: Drug testing amongst elite footballers }\end{array}$ \\
\hline Diffusion & $\begin{array}{l}\text { Description: Degree to which factor is voluntarily recognized amongst } \\
\text { society } \\
\text { Low: Recognition of discrimination based on body-weight } \\
\text { High: Recognition of discrimination based on race and gender }\end{array}$ \\
\hline \multicolumn{2}{|l|}{ Context } \\
\hline Uncertainty & $\begin{array}{l}\text { Description: Degree to which future environment is known/fixed } \\
\text { Low: Continued existence of constitutional monarchy/democracy } \\
\text { High: Status of United Kingdom within the European Union }\end{array}$ \\
\hline Interconnectedness & $\begin{array}{l}\text { Description: Degree to which environment is interrelated/coordinated } \\
\text { Low: New and emergent industries (e.g. online media providers) } \\
\text { High: Long established and regulated industries (e.g. print media) }\end{array}$ \\
\hline
\end{tabular}

Developed with reference to Oliver (1991) democracy between corporations and civil society (Scherer and Palazzo 2011) than it is a case of corporations co-opting civil society actors (Blowfield 2005, p. 182).

The negative perspective also draws on Foucault's (1972, p. 38) recognition that we all live and operate within broader "discursive formations": i.e. within orders of relations "between objects, types of statement, concepts, or 
Table 2 Strategic responses

\begin{tabular}{|c|c|c|}
\hline Strategies (and tactics) & Description & \\
\hline \multicolumn{3}{|l|}{ Acquiesce } \\
\hline Habit/imitate & Follow invisible, tacit norms & \\
\hline Comply & Obey/accept norms advanced by stakeholders & \\
\hline \multicolumn{3}{|l|}{ Compromise } \\
\hline Balance & Balance corporate and stakeholder interests & \\
\hline Pacify & Placate and accommodate external interests/stakeholders & 쭉 \\
\hline \multicolumn{3}{|l|}{ Avoid } \\
\hline Conceal & Disguise nonconformity with stakeholder supported norms & 察 \\
\hline Buffer & 'De-couple' corporate practices from professed norms & 훅 \\
\hline \multicolumn{3}{|l|}{ Defy } \\
\hline Challenge & Contest external norms and/or stakeholders & సं \\
\hline Attack & Attack or undermine external norms and/or stakeholders & \\
\hline \multicolumn{3}{|l|}{ Manipulate } \\
\hline Influence & Shape interest of external constituents/stakeholders & \\
\hline Control & Dominate/control constituents/stakeholders & \\
\hline
\end{tabular}

Oliver (1991)

thematic choices"; and that such orders are always "subjected... [to] rules of formation" that amount to a sort of power-knowledge mélange (also see Foucault 1977, pp. 23-25). As a result, the negative perspective suggests that, whatever their posited intentions, multi-stakeholder initiatives comprise a type of scientific and (soft) legal "complex" (Foucault 1977, p. 23) that can never be free from power relations; and thus, are always marked by a form of communicative and/or exclusionary 'violence' (Blowfield 2005, p. 182). More generally, the negative perspective tends toward suggesting that CSR, and a variety of its more or less closely related conceptual counterparts (e.g. environmental management, sustainable development), comprise a power-knowledge complex that emphasizes the responsibility of society towards corporations more than it does the responsibilities of corporations towards society (e.g. Banerjee 2008).

As I have already indicated, an important upshot of these Gramscian and Foucauldian insights is that they result in the negative view portraying the various manifestations of consensual CSR-e.g. multi-stakeholder initiatives, CSR reporting, environmental management programmes_in a fashion resembling Oliver's (1991) strategies of compromise and avoid. Prasad and Elmes (2005, p. 863) for example, write that:

...practical [environmental management] is equated with maintaining economic growth and success... [with] entering into alliances and agreements with specific stakeholders and ensuring low levels of societal confrontation. [Accordingly, environmental management] ultimately appears to rest on a narrow platform of economic instrumentality and on a philosophy of convenience that emphasizes minimum socio-economic disruption and maximum conflict avoidance... it frequently falls short in terms of conserving natural resources or reducing industrial pollution, while simultaneously excluding other environmental discourses... on the grounds that they are not practical enough.

Similarly, Blowfield (2005, pp. 181-182) suggests that CSR discourse portrays "success as something non-conflictual", "views dissent as a perversion", and "treats conflict as something that can be avoided through inclusive stakeholder partnerships". Amongst other things then, the negative perspective of consensual CSR suggests that both the social accounting practices of corporations (Spence 2009), and their participation within international accountability standards (Jamali 2010), will tend to be 'ceremonial'. To briefly expand, it suggests that whilst consensual CSR practices will often be characterized by some sort of compromise between corporations and their stakeholders, any compromise that is reached will either have a financial benefit (or be of no significant cost) for a corporation; or be constructed so as to ensure that corporate practices are "buffered" or "de-coupled" (Oliver 1991, pp. 154-155; Meyer and Rowan 1977) from any costs that such a compromise would otherwise entail. In contrast to the positive perspective then, which portrays multi-stakeholder initiatives like the Forest Stewardship Council, SA 8000, and the United Nations Global Compact, in terms of corporations acquiescing to and/or compromising over stakeholder demands; the negative perspective suggests they are characterized by a process of compromise and/or avoid. To put it metaphorically, the positive perspective of consensual CSR sees the 'glass' of multi-stakeholder initiatives as half-full, whilst the negative perspective sees it as half-empty. 


\section{Dissensual Corporate Social Responsibility}

In conceiving dissensual CSR, I begin with four points regarding dissensus more generally. First, issues of dissent (or consent) will often relate to theoretical/cognitive frameworks (i.e. matters of conception); pragmatic/instrumental considerations (i.e. means-end relations); and/or, axiological/normative issues (i.e. value issues) (Rescher 1993, p. 5; cf. Suchman 1995, pp. 578-586). Accordingly, issues of dissent (or consent) can be more or less complex (e.g. they can relate to one or more of a given set of normative, cognitive and pragmatic questions). Furthermore, they can be more or less pronounced (e.g. value disagreements tend to be 'deeper' than pragmatic disagreements).

Second, disagreement, discordance, and/or dissensus, is a fact of life. Rescher (1993, p. 67) for instance, argues that because experience differs "from age to age, culture to culture, and... person to person... pluralism... is an unavoidable part of the natural scheme of things" (Rescher 1993, p. 67). As a result—and in contrast to the oft made suggestion that institutions should be designed to enable the formation of consensus (e.g. Habermas 1996; O'Neill 1989)—it is also commonly suggested that institutions should be designed to account for a world marked by continuing disagreements (e.g. Rescher 1993, Chapters 8-10). Rawls (1999) for example has suggested, with this and other concerns in mind, that the international order should be respectful of 'reasonable' differences in social/ political orders within different nation-states; and that a liberal domestic order should be respectful of 'reasonable' differences in belief systems amongst its different domestic communities.

Third, not only is dissensus a fact of life, but it can be conceived as a pragmatic and/or normative positive. Progress in science for example (e.g. Kuhn 1996), and progress in our normative values (Mill 1859), is often posited to arise through dissenting, revolutionary, and not infrequently persecuted, voices. Furthermore, it is often suggested that dissenting voices can help reveal the limits of our cognitive and/or normative frameworks (e.g. Laclau and Mouffe 1985), and that they can help to reveal possibilities and "obliterated wrongs that cannot be signified within a hegemonic discourse" (Ziarek 2001, p. 86). In Foucauldian terms then, it might be suggested that dissensus, antagonism, and/or polemics (cf. Foucault 1984b), can help mobilize those "points of resistance" that make (personal and social) revolutions possible (Foucault 1978, pp. 96-97).

Fourth, and whilst the ideas of dissensus and consensus are analytically separate, they need not be considered mutually exclusive or sequentially unrelated. Positions that currently dissent against a more or less widespread consensus, for instance, can subsequently go on to be the subject thereof (e.g. Kuhn 1996; Mill 1859). And, it is obviously possible for people to agree that dissent will sometimes be socially desirable (e.g. the right to public protest); or, for people to consent to the suggestion that dissent should be allowed on various issues (e.g. matters of taste).

As these four points indicate, the idea of CSR - which relates to the management of the business-society interface and to normative and/or 'social good' issues (e.g. Gond and Moon 2011) — can be meaningfully related to the notion of dissensus. Accordingly, dissensual CSR should not be considered oxymoronic, but rather, as a possible alternative or supplement to the widely actualized consensual CSR activities outlined above.

To further clarify the differences separating dissensual from consensual CSR, the most general point to make is that, whereas consensual CSR seeks to organize and/or portray corporate-civil society accordance; dissensual CSR seeks to organize and/or portray corporate-civil society discordance. More pointedly - and rather than being associated with the corporate concern to: (a) comply with or balance stakeholder demands (i.e. the positive perspective of consensual CSR); or (b) pacify or buffer themselves from stakeholder demands (i.e. the negative perspective of consensual CSR)—dissensual CSR is associated with the corporate concern to actively seek out, acknowledge, and/ or publicize, some sort of corporate-civil society disagreement. Thus, and as Table 3 highlights, dissensual CSR is better associated with Oliver's (1991) defy strategy than it is her strategies of acquiesce, compromise or avoid.

Additionally, and whereas the positive perspective of consensual CSR in particular, suggests that the legitimacy of corporate practices depends on their being widely consented to; dissensual CSR suggests that the opposite may also be true. Indeed, a cognitive elitist with pragmatic and/ or normative intentions might suggest that it is because a corporation's activities differ from what the masses consider legitimate, that they deserve respect (Rescher 1993, p. 30).

Be this as it may, the more important point to emphasize is that, if corporations are to engage in dissensual CSR, then they need to engage more radical than reformative civil society actors: for whereas the latter seek compromise, the former do not (den Hond and de Bakker 2007). A reformative NGO like the World Wildlife Fund (WWF), for example-which seeks to "build strong partnerships with business"-is unlikely to engage in any meaningful corporate confrontation. A more radical NGO such as People for the Ethical Treatment of Animals (PETA), on the other hand, provides a much more suitable option. Indeed, given their "uncompromising stands on animal rights", and their "driving mission ... to stop animal abuse worldwide", PETA are more or less completely opposed to 
Table 3 Differentiating consensual from dissensual corporate social responsibility

\begin{tabular}{|c|c|c|c|}
\hline & \multicolumn{2}{|l|}{ More conformative } & More reformative \\
\hline & Consensual CSR & & Dissensual CSR \\
\hline Positive or negative view & Positive & Negative & NA \\
\hline General orientation & Corporate-civil society consensus & Corporate-civil society consensus & $\begin{array}{l}\text { Corporate-civil society } \\
\text { dissensus }\end{array}$ \\
\hline Strategies & Acquiesce-compromise & Compromise-avoid & Defy \\
\hline Tactics & Comply, balance & Pacify, conceal, buffer & Challenge, attack \\
\hline $\begin{array}{l}\text { Concrete CSR Practices } \\
\text { and/or Initiatives } \\
\text { associated with } \\
\text { (non-exhaustive list) }\end{array}$ & $\begin{array}{l}\text { Forest Stewardship Council (Scherer } \\
\text { and Palazzo 2007); SA } 8000 \text { (Gilbert } \\
\text { and Rasche 2007); United Nations } \\
\text { Global Compact (Scherer and } \\
\text { Palazzo 2011); 'Discursive } \\
\text { Engagement' and/or 'Deliberative } \\
\text { Democracy' (Gilbert and Rasche } \\
\text { 2007; Scherer and Palazzo 2011) }\end{array}$ & $\begin{array}{l}\text { Forest Stewardship Council } \\
\text { (Blowfield 2005); SA } 8000 \\
\text { (Jamali 2010); United Nations Global } \\
\text { Compact (Jamali 2010); 'Environmental } \\
\text { Management' (Prasad and Elmes 2005); } \\
\text { 'Social Accounting' (Spence 2009); } \\
\text { 'Stakeholder Engagement' (Blowfield 2005) }\end{array}$ & $\begin{array}{l}\text { Dissent enabling public } \\
\text { spheres }\end{array}$ \\
\hline
\end{tabular}

a whole host of corporate activities (e.g. animal slaughter by fast food retailers). In much the same fashion, more radical or 'deep' environmentalists (e.g. Naess 1973) provide a good corporate opponent due to their scepticism of capitalist enterprise more generally (cf. Melucci 1996).

\section{Dissent Enabling Public Spheres}

I now suggest that dissent enabling public spheres provide one, and perhaps the most suitable means, by which a corporation can concretely realize dissensual CSR. In addition to being helpfully contrasted with the above discussed multi-stakeholder initiatives, which can be considered a sort of 'consent oriented public sphere'; what I term 'dissent enabling public spheres' are helpfully conceived as an "assemblage" (Deleuze and Guattari 1988, p. 37) of certain ideas discussed by Habermas and Foucault. In light of such-and given that Habermas and Foucault are commonly (and not unreasonably) posited as being theoretical opposites (e.g. Scherer and Palazzo 2007, p. 1097)—I begin with a clarification.

Specifically, I note that whilst the works of Habermas and Foucault are opposable-in that the former is largely concerned with universal rationality (e.g. Habermas 1990) and the latter with historical rationalities (e.g. Foucault 1972) - the two need not be considered mutually exclusive. Indeed, Habermas (1986) has suggested that Foucault was ultimately 'pulled back' into the same modern philosophical tradition that he himself occupies; and Foucault (1984c, pp. 248-249) that whilst he and Habermas explored different questions, he was "completely in agreement" with Habermas's belief "that if one abandons the work of Kant... for example, we run the risk of lapsing into irrationality".
With that clarified - and given that the broader projects of Habermas and Foucault are widely discussed in considerable detail throughout the humanities and social sciences (e.g. Gutting 1994; Heath 2001) - I now turn to the specific task of conceiving dissent oriented public spheres. I emphasize four points in doing so. First, I note that I appropriate Habermas's (1989) idea of the public sphere because it helpfully describes communications that are more or less widely accessible to, and potentially participated in by, variable parties.

Second, I highlight that in The Structural Transformation of the Public Sphere (1989), Habermas famously documents the manner in which commercially oriented actors-i.e. coffee houses and newspapers-helped construct the public sphere(s) within which norms of social integration became freely debated within the UK, and subsequently elsewhere (e.g. France), from the mid-seventeenth century onwards. Accordingly, it is not much of a conceptual leap to suggest that businesses can also play a role in the creation of contemporary and dissent enabling public spheres.

Third, I emphasize that dissent enabling public spheres are not necessarily consistent with the general tenor of Habermas's work. In particular, I note that whereas Habermas tends to suggest that public spheres should be arranged to ensure that the "force of the better argument" will enable all parties to reach a rational agreement (e.g. Habermas 1996, p. 103); the notion I am conceiving suggests that public spheres can also be arranged to highlight existing or potential points of disagreement. Furthermore, I note that dissent enabling public spheres do not have to "provide for an acquiescence in disagreement" (Rescher 1993 , p. 158). Indeed, they could potentially lead to a further escalation of conflict. 
Finally, I argue that, by enabling the emergence of discordance and/or conflict, dissent enabling public spheres can help to negatively and positively reveal the extent to which "relations of communications" are largely inseparable from "relations of power" (Foucault 1987, p. 18). In terms of their negative revelatory potential then, I suggest that dissent enabling public spheres and/or CSR practices can help highlight the extent to which consent oriented public spheres and/or CSR practices-e.g. the multistakeholder initiatives described above-tend towards the exclusion of 'irrational' or 'impractical' voices (e.g. Blowfield 2005; Prasad and Elmes 2005). And in terms of their positive revelatory potential, I suggest that dissent enabling public spheres and/or CSR practices can help those who are 'silenced' by consent-oriented public spheres and/or CSR practices to positively 'voice' their own positions. Importantly in this last regard, I am not suggesting that dissent enabling public spheres would enable "relations of power" to be "dissolve[d]... in the utopia of a perfectly transparent communication". Rather, I am suggesting that they "allow these games... to be played with a minimum of domination" (Foucault 1987, p. 18).

To bring the discussion of this and the preceding section to a close, I emphasize that whilst I have touched on various normative issues, I have been primarily concerned to conceptually differentiate consensual and dissensual CSR. In particular, I have noted that consensual CSR can be associated with multi-stakeholder initiatives that (ostensibly) seek to align or balance corporate- and civil-society interests for normative and/or pragmatic reasons. On the other hand, I have suggested that dissent enabling public spheres-e.g. multi-stakeholder initiatives that seek to organize or publicize corporate-civil society discordanceprovide a specific means by which corporations can engage in dissensual CSR.

With these distinctions made, I now suggest that corporations (and/or managers) can choose to engage in either consensual or dissensual CSR at a given point in time. More specifically, I outline why I consider an economic actor-centred institutional perspective particularly well suited to explaining CSR activities at the corporate level.

\section{An Economic Actor-Centred Institutional Perspective}

Within the management literature, (neo-)institutional theory tends to emphasize the environment over the actors within it (Kostova et al. 2008); and/or, a class of actors over the individuals of which it is comprised (e.g. Greenwood and Hinings 1996, p. 1026). In short, contemporary institutional theorists tend to suggest that individual actors-be they persons or corporations - are inclined to unthinkingly or isomorphically acquiesce to existing roles or ideals; and/or, to deliberately imitate external practices, or act upon external demands, in an effort to improve their chances of being perceived as legitimate and/or suitable for a given task (Oliver 1991, pp. 152-153). More generally, institutional theorists tend to suggest that there are overlapping and taken for granted background norms or conditions that significantly enable various forms of social interaction.

Although (neo-)institutional theory enjoys considerable popularity within the management studies literature, it is commonly critiqued for understating the extent to which different agents respond to similar (but variable and often competing) institutional pressures, in different ways. Indeed, there now exists a considerable (and diverse) literature that seeks to redress this imbalance: e.g. through the idea of institutional entrepreneurship (e.g. Levy and Scully 2007), or through combining institutional and resource dependency theories (e.g. Oliver 1991). In contributing to this broad line of thought, I suggest that the idea of an actor-centred institutional perspective is particularly useful. I distinguish four types.

What I term a sociological actor-centred institutional perspective has recently been outlined by Aguilera and Jackson (2010: 532). Of the four perspectives here described, it is the most closely related to conventional institutional theory: for it emphasizes that different actors are socially embedded and/or influenced, and that their identities and/or interests are internally shaped by their external institutional environments. Amongst other things then, the sociological perspective suggests that different individuals will react to similar institutional pressures in different ways due to their possessing different, sociologically informed, identities and interests.

An ethical actor-centred institutional perspective, on the other hand, emphasizes that individuals can use their independent reasoning capacities to determine whether or not they should comply with, resist, or seek to transform, various institutional pressures. Thus, and whilst these different actors may or may not form their understanding through communicative acts (Habermas 1990), the key point to emphasize is that individual ethical (and/or moral) actors (cf. Habermas 1995, pp. 112, 126) can themselves decide how to respond to different institutional pressures (e.g. those relating to abstinence from alcohol, marital fidelity, meat eating) on the basis of normative reasoning.

The transformative perspective is the third actor-centred perspective. It draws on elements of the sociological and ethical perspectives without being reducible to either. Specifically, it involves a person using a sort of ethical agency to transform their already existent, and sociologically informed, actor-hood. The person involved, however, does not use their 'ethical' agency out of a concern to comply with existing norms. Rather, they use it in an effort to (continuously) transgress and transform their own ways 
of being (Foucault 1984a, pp. 45-47). Arguably, this transformative actor-centred institutionalism is the most agentic of all the perspectives here outlined. Nevertheless - and whereas it may have considerable relevance for the analysis of those involved in deep philosophical investigations, radically transgressive behaviours, and/or new social movements (e.g. Melucci 1996)—it arguably has the least immediate relevance to decision making within corporations.

By way of contrast, what I term the economic actorcentred institutional perspective is applicable to a whole host of decision making complexes within corporations. In short, this fourth perspective suggests that corporate managers make decisions on the basis of pragmatic strategic considerations: e.g. 'profit-maximization'. This 'selfinterested' understanding of actor-hood is commonly employed, in slight variations, throughout the social sciences. In political science (Downs 1957) and international relations (Moravcsik 2000) for instance, the concern with profits tends to be replaced or supplemented with the concern to seize or maintain power.

Importantly, an economic actor-centred institutional perspective can overlap with the sociological and ethical perspectives (and perhaps the transformative perspective as well). Various sociological and/or political factors for instance-e.g. business school educations (Ghoshal and Moran 2005) and corporate governance structures (Sealy and Worthington 2008) — contribute to corporate managers commonly conceiving of corporate profitability as being important. Further, it is likely that some managers focus on corporate profitability because they think it is ethically correct for one reason or another (see Heath and Norman 2004 for some possible justifications in this regard). In short, and as casual empirical analysis confirms (of CSR websites, reports and practices for instance), an economic actor-centred institutionalism is an expedient and empirically realistic theoretical option for explaining CSR policies at practices at the corporate level.

More specifically, and as I have already indicated above, I suggest that an economic perspective is helpful due to it suggesting that managers will be inclined to adopt dissensual over consensual CSR when they believe that defiance of civil society pressures is likely to prove more profitable than the use of acquiesce, compromise and/or avoid strategies with regard thereto (Oliver 1991). In this specific fashion then, and as Table 4 clarifies, the economic perspective differs from the other three actor-centred institutional perspectives (which themselves differ from each other).

\section{Shell and the Construction of a Dissent Enabling Public Sphere}

As institutional theory suggests, the emergence and widespread adoption of consensual CSR practices can be understood as relating to institutional pressures at two levels of analysis. First, and most immediately, it relates to the 'direct' pressures that corporations face with regard to improving their moral and/or social performance. Second, and somewhat more generally, it relates to the pressures that corporations face to engage in consensual CSR activities as a form or style of practice (e.g. Blowfield 2005; Shanahan and Khagram 2006).

Whilst these pressures undoubtedly contribute to the widespread proliferation of consensual CSR, the general point made in the preceding section is that actors possess an agency that need not result in their being acquiesced to (and/or isomorphically adopted). More specifically, I have argued that an economic actor-centred institutional perspective suggests that corporate managers will be inclined

Table 4 Four actor-centred institutional explanations of consensual and dissensual CSR

\begin{tabular}{|c|c|c|}
\hline \multirow{2}{*}{$\begin{array}{l}\text { Actor-centred } \\
\text { institutional perspective }\end{array}$} & \multicolumn{2}{|l|}{ Explanation of the adoption of } \\
\hline & Consensual CSR & Dissensual CSR \\
\hline Sociological & $\begin{array}{l}\text { Cultural and/or professional interest/identity that } \\
\text { emphasizes need for interest alignment between } \\
\text { corporations and civil society. A more democratic } \\
\text { than liberal disposition }\end{array}$ & $\begin{array}{l}\text { Cultural and/or professional interest/identity that } \\
\text { emphasizes the need for corporate-civil society } \\
\text { discordance to be publicized or enabled. A more } \\
\text { liberal than democratic disposition }\end{array}$ \\
\hline Ethical & $\begin{array}{l}\text { Managerial belief that corporate-civil society } \\
\text { agreement needs to be maintained or constructed } \\
\text { to ensure moral legitimacy of corporate practices }\end{array}$ & $\begin{array}{l}\text { Managerial belief that the enabling or promotion of } \\
\text { corporate-civil society discordance is morally } \\
\text { correct: e.g. because it promotes social progress }\end{array}$ \\
\hline Transformative & $\begin{array}{l}\text { Manager fails to 'free' themselves from } \\
\text { conventional and consent privileging CSR role/ } \\
\text { discourse }\end{array}$ & $\begin{array}{l}\text { Manager 'frees' themselves from conventional CSR } \\
\text { role/discourse to create a new dissent enabling } \\
\text { function }\end{array}$ \\
\hline Economic & $\begin{array}{l}\text { Managerial belief that profitability is most likely to } \\
\text { be achieved by acquiescing to, compromising } \\
\text { over, or avoiding, civil society pressures }\end{array}$ & $\begin{array}{l}\text { Managerial belief that profitability is most likely to } \\
\text { be achieved by defying civil society pressures }\end{array}$ \\
\hline
\end{tabular}


to adopt dissensual over consensual CSR practices, in a given specific instance, so long as they believe that the former is the financially prudent, or most beneficial, option. It is in illustrating this basic line of argument, then, that I now analyse a dissent enabling public sphere that Shell has recently constructed.

\section{Shell, Brent Spar and Corporate Social Responsibility}

Shell is an Anglo-Dutch petro-giant who commonly ranks amongst the world's top ten companies in terms of revenues. The majority of their earnings are made 'upstream' in fossil fuels: i.e. in the search and recovery of oil and natural gas, the liquification and transportation of gas, and the operation of the infrastructure required to deliver oil and gas to market. Nevertheless, Shell also generates at least some minimal income from various renewables such as biofuels and wind. Furthermore, they often express a broad commitment to environmental responsibility and/or sustainable development, and to being concerned with climate change (Shell 2012).

Given the nature of their operations, Shell are often subject to critique from civil society actors. Radical environmental activists for example, regularly target Shell in their various campaigning activities. Perhaps most memorably, Greenpeace vanquished Shell in the Brent Spar 'battle' of 1995 (e.g. Bakir 2005; Grolin 1998; Tsoukas 1999). This battle was a public relations disaster that contributed, amongst other things, to the fire-bombing of two Shell outlets in Germany (Tsoukas 1999, p. 515). More importantly, the campaign-which received significant media attention, and involved Greenpeace activists occupying the Brent Spar oil buoy (an oil storage device) resulted in Shell abandoning their plans to sink the oil buoy in the North Atlantic; and to their towing it to Norway, where parts of it were used to help construct an industrial quayside (Bennie 1998, p. 397).

Since the Brent Spar episode, Shell has undergone major reviews of their CSR and communicative practices (e.g. Coupland and Brown 2004). Most importantly in the present context, they created Shell Dialogues (in 1998) as a means by which to work "with a number of media organisations around the world to produce events, articles and broadcasts so our key stakeholders can debate the burning issues" (Shell Dialogues). The 2009 'BBC World Debate' on 'The Future of Fossil Fuels' that Shell produced in association with BBC World News, is one example of a Shell Dialogues event.

Shell's BBC World Debate: 'The Future of Fossil Fuels'

To give an indication as to the potential 'reach' of this specific debate, I note that BBC World News, the "commercially funded, international" arm of the BBC, broadcasts "in English in more than 200 countries and territories across the globe" to an "estimated weekly audience reach of 74 million" (BBCWN). Further, I note that the debate was televised prior to the 2009 United Nations Copenhagen Climate Change Conference, where it was hoped that world leaders would reach agreement on reducing $\mathrm{CO}_{2}$ (equivalent) emissions (see COP15 2009).

The debate itself featured the following parties: Emily Rochon from Greenpeace International; John Mills from Shell; Neil Hirst from the International Energy Agency; Heleen de Coninck, from the Energy Research Centre of the Netherlands; and Chris Schroeder from Qatar Airways. As emerged during the debate, and as detailed in Table 5 below, various differences separated the five panellists. Most importantly, the debate revealed an effective chasm between the positions held by Greenpeace's Emily Rochon and Shell's John Mills on such issues as energy demand levels in 2050-2060; fossil fuel requirements in 2050-2060; and carbon capture and storage (CCS) technology (a technology which first 'captures' carbon from fossil fuel power plants, and then injects the carbon into the earth's geo-structure).

In general terms, the debate revealed significant differences on both theoretical/cognitive matters (e.g. with regard to predicted energy demand levels) and pragmatic/ instrumental considerations (e.g. with regard to the workability of alternative energy technologies as opposed to CCS). On the other hand, the debate did not reveal any significant differences with regard to axiological/normative issues. Indeed, the debate was founded on a consensus regarding the need to reduce $\mathrm{CO}_{2}$ (equivalent) emissions, and that climate change is undesirable more generally.

Given that the debate itself was largely 'silent' on value issues, it is important to emphasize that Shell and Greenpeace can be characterized in terms of underlying value differences. With regard to Shell then, it is fairly clear that, as one of the world's largest and most recognizable corporations, it is predisposed towards recognizing the merits of capitalism in its various (state and market) guises. Greenpeace, on the other hand, is an "independent global campaigning organisation" that seeks "to protect and conserve the environment"; does "not accept donations from governments or corporations"; and that "challenge[s] government and corporations when they fail to live up to their mandate to safeguard our environment and our future" (GI). Thus-and whilst Greenpeace profess to "have no permanent allies or enemies", and does lend support to various consent oriented CSR initiatives (GI) - it is far from being pro-capitalism (e.g. Naidoo 2009).

The question that needs to be answered, then, is why would Shell construct a public sphere that enables Greenpeace to voice opinions that so clearly disagree with their 
Table 5 Positions advanced during 'the future of fossil fuels' debate

\begin{tabular}{|c|c|c|c|c|c|}
\hline $\begin{array}{l}\text { Participant, } \\
\text { affiliation }\end{array}$ & $\begin{array}{l}\text { Can fossil } \\
\text { fuels be } \\
\text { clean and } \\
\text { green? }\end{array}$ & $\begin{array}{l}\text { Can carbon } \\
\text { capture work at } \\
\text { scale? }\end{array}$ & $\begin{array}{l}\text { Can energy demands } \\
\text { in } 2050-2060 \text { be } \\
\text { limited to today's } \\
\text { levels? }\end{array}$ & $\begin{array}{l}\text { Can fossil fuels be } \\
\text { effectively phased out by } \\
2050-2060\end{array}$ & General points \\
\hline $\begin{array}{l}\text { Emily Rochon, } \\
\text { Greenpeace }\end{array}$ & $\begin{array}{l}\text { Absolutely } \\
\text { not }\end{array}$ & $\begin{array}{l}\text { Potentially in the } \\
\text { longer term } \\
\text { ( } 20 \text { years). } \\
\text { Currently } \\
\text { unproven }\end{array}$ & $\begin{array}{l}\text { Yes, via the judicious } \\
\text { employment of } \\
\text { efficiency measures }\end{array}$ & $\begin{array}{l}\text { Yes, renewable resources, } \\
\text { and alternative energy } \\
\text { technologies, can supply } \\
\text { what the world needs }\end{array}$ & $\begin{array}{l}\text { Emissions need to peak globally } \\
\text { between now and } 2015 \text {. Coal } \\
\text { cannot play a significant role if } \\
\text { this goal is to be achieved }\end{array}$ \\
\hline John Mills, Shell & $\begin{array}{l}\text { Can and } \\
\text { need to } \\
\text { be } \\
\text { greener }\end{array}$ & $\begin{array}{l}\text { Yes, in the short- } \\
\text { medium term } \\
\text { (from } 2012 \\
\text { onwards) }\end{array}$ & $\begin{array}{l}\text { No, they will double } \\
\text { due to population } \\
\text { and per-capita } \\
\text { consumption } \\
\text { increases }\end{array}$ & $\begin{array}{l}\text { No, they will still be } \\
\text { required to meet approx. } \\
\text { two-thirds of energy } \\
\text { demands }\end{array}$ & $\begin{array}{l}\text { Coal power stations are being built } \\
\text { globally and will increasingly be } \\
\text { built in transition economies: } \\
\text { e.g. China }\end{array}$ \\
\hline $\begin{array}{l}\text { Neil Hirst, } \\
\text { International } \\
\text { Energy Agency }\end{array}$ & $\begin{array}{l}\text { Can and } \\
\text { need to } \\
\text { be } \\
\text { greener }\end{array}$ & $\begin{array}{l}\text { Yes, in the short- } \\
\text { medium term }\end{array}$ & Unlikely & $\begin{array}{l}\text { Partially. There will need } \\
\text { to be a mix of energy } \\
\text { sources to meet demand }\end{array}$ & $\begin{array}{l}\text { We need to be committing } \\
\text { resources to multiple and various } \\
\text { technologies }\end{array}$ \\
\hline $\begin{array}{l}\text { Heleen de } \\
\text { Coninck, } \\
\text { Energy } \\
\text { Research Centre } \\
\text { of the } \\
\text { Netherlands }\end{array}$ & No & $\begin{array}{l}\text { Yes, in the short- } \\
\text { medium term }\end{array}$ & NA & $\begin{array}{l}\text { Partially. There will need } \\
\text { to be a mix of energy } \\
\text { sources to meet demand }\end{array}$ & $\begin{array}{l}\text { Development of technologies like } \\
\text { carbon capture will require } \\
\text { considerable resources and } \\
\text { political will }\end{array}$ \\
\hline $\begin{array}{c}\text { Chris Schroeder, } \\
\text { Qatar Airways }\end{array}$ & No & NA & Unlikely & $\begin{array}{l}\text { Fossil fuels only option for } \\
\text { the foreseeable future in } \\
\text { aviation industry }\end{array}$ & $\begin{array}{l}\text { Don't want to rely on fossil fuels. } \\
\text { If other technologies are } \\
\text { available, would willingly use }\end{array}$ \\
\hline
\end{tabular}

own? An economic actor-centred institutional perspective points towards three (overlapping) explanations. First, the fact that Greenpeace vanquished Shell in the Brent Spar 'battle' of 1995-which was ostensibly over the best method by which to dispose of an oil buoy (i.e. a theoretical and/or pragmatic question)—-means that Shell are well aware that the failure to confront the theoretical and/or pragmatic beliefs of radical NGO voices can result in commercial damage. Accordingly, they appear to have decided that it was better, in this specific instance, to bring these theoretical and pragmatic differences to the fore; rather than wait for Greenpeace to do it for them. In other words, Shell took partial control of the way in which their own reasoning was represented, whilst simultaneously managing to acknowledge Greenpeace's differing point of view (which Greenpeace was communicating, and still is communicating, by their own independent means).

Second, the idea that fossil fuels will only be needed to a minimal extent by 2050-2060, a position advanced by Greenpeace, is inimical to Shell's core business operations, and thus, one that Shell cannot acquiesce to or easily compromise over within a consensual CSR framework. Shell, however, still faces the risk that Greenpeace might prove capable of convincing a variety of powerful stakeholders, such as governments and/or consumers for instance, that their position is feasible and desirable (as they partially did in the case of Brent Spar). Accordingly, Shell's decision to construct a public sphere within which Greenpeace could publicly express, and Shell could publicly disagree with, their claims, makes general sense. Importantly, and as Table 5 summarizes, Shell's belief that fossil fuels will still be needed to some considerable extent in 2050-2060, was broadly agreed to by all the participants except Greenpeace. In this fashion then, the dissent enabling public sphere actually points towards a partial (but not necessarily stable) consensus.

Third, Greenpeace's suggestion that CCS technology is unlikely to work in the short- to medium-term future is not only a potentially significant hindrance to Shell's exiting fossil fuels business (which arguably depends on the world's capacity to reduce $\mathrm{CO}_{2}$ emissions), but also to a potentially lucrative new one. The basic reason being that, in addition to requiring that $\mathrm{CO}_{2}$ emissions be captured (by chemicals for example), and subsequently stored underground (e.g. in depleted oil and gas reservoirs), CCS involves the replacement of a "coal-fired plant with a gasfired plant that has CCS" technology and that can potentially "cut $\mathrm{CO}_{2}$ emissions by up to $90 \%$ " (Shell). Indeed, the International Energy Agency suggests that "CCS... could contribute as much as $19 \%$ of the $\mathrm{CO}_{2}$ mitigation 
effort required by 2050" (Shell 2012, p. 50). With these points in mind, then, CCS can be considered a potential 'double-win' for Shell: for the company is well placed to help make CCS work in the first place, and can also supply natural gas to the new gas-fired power plants that would subsequently be needed (Shell 2012, p. 50). Nevertheless, and as Greenpeace's Emily Rochon makes clear in the debate, currently working CCS initiatives amount to approximately $1 / 6000$ th of that which the International Energy Agency suggests is needed to tackle climate change. Thus, and whilst there is some obvious potential upside to Shell's highlighting the possibilities of CCS, there is also some potentially considerable downside if they were to place too much emphasis upon it.

\section{Discussion}

The first point to make in discussing 'The Future of Fossil Fuels Debate' is that the economic actor-centred institutional perspective I have utilized provides a different explanation to those that either the sociological or ethical perspectives would likely provide. Specifically, the former would be inclined to explain these dissensual CSR activities with reference to the changing identities and/or interests of Shell decision-makers; and the later with reference to their processes of normative reasoning. By way of contrast, the economic perspective suggests that the reason for Shell decision-makers employing dissensual CSR in this specific instance, is because they thought a defy strategy more prudent than a strategy of acquiesce, compromise, and/or avoid.

The employment of such dissensual CSR practices, however, comes with considerable risks. Specifically, and as I have just indicated in noting that CCS remains in its practical infancy, the debate could potentially contribute to key stakeholders (e.g. politicians) believing that climate change cannot be managed by such means. Rather, it might result in them thinking that it requires significant reductions in fossil fuels usage. Thus, instead of encouraging government support for the continued viability of fossil fuels and the development of CCS technologies, which Shell (2012, pp. 50-51) publicly advocate, the debate might contribute to pressures moving in the other direction.

Clearly, this is something that Greenpeace would welcome, and was no doubt the reason for Greenpeace's Emily Rochon participating in the debate in the first place. However, and just as Shell face risks through constructing the dissent enabling public sphere, Greenpeace face risks participating within it. Most pointedly, Greenpeace run the risk of being positively marginalized (as opposed to negatively marginalized in the sense indicated by the negative perspective on consensual CSR). In particular, I note that, by suggesting that the world's reliance on fossil fuels can effectively be phased out by 2050-2060, Greenpeace was the clear outlier in 'The Future of Fossil Fuels' debate. Further, by using the debate to make statements such as"if our priority is climate change, you cannot continue to increase our reliance on fossil fuel"-Emily Rochon might be perceived as suggesting that Greenpeace is not overly concerned with such issues as energy security and cost. In short, Greenpeace run the risk of portraying themselves as impractical.

Whilst there are potential risks to both Shell and Greenpeace from constructing and/or participating within such a dissent enabling public sphere, I suggest that, given the right circumstances, both parties would likely construct and/or participate within one again. The general reason why is that, unlike consensual CSR, dissensual CSR enables corporations and more radical civil society actors to confront each other over issues of fundamental commercial importance (in ways that do not involve direct physical violence). Interestingly, even when there is a 'loser' from the immediate confrontation, this 'loser' can still be perceived to have benefitted from the confrontation. Greenpeace for example, who might be perceived to have lost certain key aspects of 'The Future of Fossil Fuels Debate', are likely to have strengthened their radical credentials in the eyes of some because of their refusal to be 'practical' and seek to 'win' the debate. By way of contrast, if they were to be the 'loser' within a consensual CSR initiative, then they run the risk of being perceived to have lost in two senses: for not only have they compromised 'more' than their corporate partner, but they also had to agree to compromise or 'sell out' in the first place.

In addition to being of potential benefit to the various participants within them, it is possible to identify at least four (competing) reasons for thinking that dissent enabling public spheres can contribute to the social good more generally. First, the voicing of dissent might contribute to the formation of a broader and stronger consensus on the specific issues discussed further down the line. It is possible, for example, that either Shell or Greenpeace, or those who support them, will ultimately come round to the other's view in a socially progressive fashion. As noted above, this sort of progressive possibility of dissent has long been recognized (e.g. Mill 1859; cf. Rescher 1993, p. 46).

A conservative argument, on the other hand, might suggest that dissent enabling public spheres help demonstrate that 'moralizing' is inconsistent with the functional operation of sub-systems in modern societies (e.g. markets; judiciaries); and that they can thus act to strengthen community support for such sub-systems operating free there from (Luhman 1993). More specifically, through highlighting more radical 'moralizing' voices, dissent enabling public spheres might encourage the general public to 
question whether or not corporations should even entertain the more reformative 'moralizing' voices that are associated with consensual CSR (e.g. Willke and Willke 2008).

In a slightly different fashion, it might be suggested that dissent enabling public spheres are socially beneficial because they encompass and demonstrate the reality of social difference. Amongst other things, this plural perspective suggests that dissent enabling public spheres can help to reveal that a social consensus is highly unlikely on certain issues, not needed on certain issues, and/or, that the effort to achieve a specific consensus is not worthwhile. In short, it might help society acknowledge that social harmony is not so much a matter of consensus, as it is a matter of agreeing to "live and let live', so that we avoid letting our differences become a causus beli between us" (Rescher 1993 , p. 132). Whilst this perspective is likely to be considered overly passive by many (e.g. supporters of consensual CSR), it might be considered very suitable by others: e.g. by multinational corporations seeking to manage their complex moral environment around the globe.

Finally, a transformative perspective suggests that corporate constructed and dissent oriented public spheres are of social value due to their potentially leading to some sort of revolutionary change. Someone might, for example, think that the confrontation between Shell and Greenpeace is the upshot of both their underpinning worldviews being 'mistaken' (for potentially much the same reason); and thus seek an alternative worldview that does not suffer the same problems. Importantly, the transformative perspective of which I am thinking is less dialectical and rational than it is creative and esoteric. It promises the possibility of societies being partially redesigned anew in ways that can only be recognized ex post facto (e.g. Foucault 1984a).

\section{Conclusion}

In the present paper I have made three key contributions. First, I have noted the consensual tendencies of the CSR literature more generally, and conceived of both a positive and negative perspective of consensual CSR in non-normative terms. Second, I have conceived of dissensual CSR, and argued that dissent enabling public spheres are a primary means by which corporations can actualize dissensual CSR practices. Third, I have differentiated between four actor-centred institutional perspectives, and argued that an economic actor-centred institutional perspective is particularly well suited to the analysis of CSR at the corporate level. Additionally, I have used this economic perspective to analyse a dissent enabling public sphere that Shell has recently constructed.

Further to making these contributions, the paper suggests at least four topics that scholars interested in business and society interactions might pursue in future research. First, and most obviously, there is more work needed with regard to identifying and investigating other examples of dissensual CSR. As I have indicated throughout the paper, consensual CSR is the status quo with regard to both CSR practice and scholarship. Nevertheless, corporations other than Shell-such as E.ON UK-have engaged in dissensual CSR practices, and have helped construct a form of dissent enabling public sphere (E.ON Talking Energy). Accordingly, it would be interesting for future work to identify and analytically differentiate the various dissensual CSR policies and practices that are possible or currently actualized; and/or, to further explain why such dissensual CSR practices are chosen over, or are likely to be chosen over, their consensual counterpart.

Second, there is a need for work that investigates the normative underpinnings of dissensual CSR, and that compares and contrasts these underpinnings with those of consensual CSR. As noted in the paper's introduction, I have here engaged in descriptive-explanatory theorizing, and not normative-prescriptive theorizing. Thus, and whilst I have necessarily discussed various normative issues throughout the paper, these discussions are no more than a beginning. Accordingly, I suggest that one or more of the four 'social good' perspectives that I have above outlined on dissensual CSR-i.e. the progressive, conservative, plural, and transformative perspective, respectively-could provide a good starting point from which to proceed.

Third, it would be interesting for future work to investigate the manner in which broad social trends, and/or macrosocial developments, are likely to impact upon the future adoption of consensual and/or dissensual CSR practices. The continuing spread of information and communication technologies (ICTs), for example might be thought to necessitate that corporations increasingly adopt dissensual CSR practices: for ICTs potentially enable those with fringe or radical views to more easily mobilize against a corporation whose practices they consider illegitimate (for one reason or another). Further, the continuing reality of religious differences, moral differences, and/or sociological differences, around the globe, might result in multinational corporations increasingly coming to think that, in certain circumstances, consensual CSR is entirely impractical.

Finally, the paper highlights the need for more nuanced and sophisticated work on the theoretical foundations of descriptive and explanatory CSR research. In particular, I suggest that developments of one or more of the actorcentred institutional perspectives I have here outlined, could prove particularly beneficial. Such research might employ a variety of approaches. It might, for instance, seek to more fully demonstrate the ways in which sociological and ethical considerations support and/or help create the 
economic perspective. Alternatively, it might seek to demonstrate or clarify the manner in which each of the different perspectives are relevant (and/or most suited to) explaining different subsets of business-society interactions; and/or, to explaining why the different perspectives are relevant at different levels of analysis.

Acknowledgments I am very grateful for the helpful comments of the editorial team and reviewers. The paper also benefited from comments received on an earlier version of the paper that was presented at the EGOS workshop on 'Social Movements, Civil Societies and Corporations' at Margaux in May 2010.

\section{References}

Aguilera, R. V., \& Jackson, G. (2010). Comparative and international corporate governance. The Academy of Management Annals, 4(1), 485-556.

Bakir, V. (2005). Greenpeace v. Shell: Media exploitation and the social amplification of risk framework (SARF). Journal of Risk Research, 8(7-8), 679-691.

Banerjee, S. B. (2008). Corporate social responsibility: The good, the bad and the ugly. Critical Sociology, 34(1), 51-79.

BBCWN (British Broadcasting Corporation World News). (2009). The future of fossil fuels. Retrieved December 21, 2012 from http://www.bbcworldnews.com/pages/ProgrammeFeature.aspx? id=196andFeatureID=1251.

Bennie, L. G. (1998). Brent Spar, Atlantic oil and Greenpeace. Parliamentary Affairs, 51(3), 397-410.

Blowfield, M. (2005). Corporate social responsibility-The failing discipline and why it matters for international relations. International Relations, 19(2), 173-191.

COP15. (2009). 15th Conference of the Parties to the United Nations Framework Convention on Climate Change, Copenhagen Accord, December 18, 2009. Retrieved December 21, 2012, from http://unfccc.int/resource/docs/2009/cop15/eng/107.pdf.

Coupland, C., \& Brown, A. D. (2004). Constructing organizational identities on the Web: A case study of Royal Dutch/Shell. Journal of Management Studies, 41(8), 1325-1347.

Deleuze, G., \& F. Guattari. (1988). A thousand plateaus: Capitalism and schizophrenia (B. Massumi, Trans.). Minneapolis: University of Minnesota Press.

den Hond, F., \& de Bakker, F. G. A. (2007). Ideologically motivated activism: How activist groups influence corporate social change activities. Academy of Management Review, 32(3), 901-924.

Donaldson, T., \& Dunfee, T. W. (1994). Toward a unified conception of business ethics: Integrative social contracts theory. Academy of Management Review, 19(2), 252-284.

Downs, A. (1957). An economic theory of democracy. New York: Harper and Row.

E.ON Talking Energy: YouTube Channel. Retrieved December 21, 2012, from http://www.youtube.com/user/talkingenergy.

Evan, W. M., \& Freeman, R. E. (1988). A stakeholder theory of the modern corporation: Kantian Capitalism. In T. Beauchamp \& N. Bowie (Eds.), Ethical theory in business (3rd ed., pp. 97-106). Englewood Cliffs: Prentice Hall.

Foucualt, M. (1972). The archaeology of knowledge (A. Sheridan Smith, Trans.). London: Routledge.

Foucault, M. (1977). Discipline and punish: The birth of the prison (A. Sheridan, Trans.). New York: Random House.

Foucault, M. (1978). The history of sexuality, Volume 1: An introduction (R. Hurley, Trans.). New York: Vintage Books.
Foucault, M. (1984a). What is enlightenment? In P. Rainbow (Ed.), The Foucault Reader (pp. 32-50). London: Penguin Books.

Foucault, M. (1984b). Polemics, politics, and problematization. In P. Rainbow (Ed.), The Foucault Reader (pp. 381-391). London: Penguin Books.

Foucault, M. (1984c). Space, knowledge, power. In P. Rainbow (Ed.), The Foucault Reader (pp. 239-256). London: Penguin Books.

Foucault, M. (1987). The ethic of care for the self as a practice of freedom: An interview with Michel Foucault, January 20, 1984. In J. Bernauer \& D. Rasmussen (Eds.), The Final Foucault (pp. 1-20). Cambridge: The MIT Press.

FSC (Forest Stewardship Council). Retrieved December 21, 2012, from http://www.fsc.org/.

Ghoshal, S., \& Moran, P. (2005). Towards a good theory of management. In J. Birkinshaw \& G. Piramal (Eds.), Sumantra Ghoshal on management: A force for good (pp. 1-27). London: FT Prentice Hall.

GI (Greenpeace International). Retrieved December 21, 2012, from http://www.greenpeace.org/.

Gilbert, D. U., \& Rasche, A. (2007). Discourse ethics and social accountability: The ethics of SA 8000 . Business Ethics Quarterly, 17(2), 187-216.

Gilbert, D. U., Rasche, A., \& Waddock, S. (2011). Accountability in a global economy: The emergence of international accountability standards. Business Ethics Quarterly, 21(1), 23-44.

Gond, J. P., \& J. Moon. (2011). Corporate social responsibility in retrospect and prospect: Exploring the life-cycle of an essentially contested concept, ICCSR Research Paper Series, No. 59, 2011. Nottingham: Nottingham University Business School.

Gramsci, A. (1971). Selections from Prison Notebooks (Q. Hoare \& G. Nowell Smith, Eds. \& Trans.). New York: International Publishers.

Greenwood, R., \& Hinings, C. R. (1996). Understanding radical organizational change: Bringing together the old and the new institutionalism. Academy of Management Review, 21(4), 1022-1054.

Grolin, J. (1998). Corporate legitimacy in risk society: The case of Brent Spar. Business Strategy and the Environment, 7(4), 213-222.

Gutting, G. (Ed.). (1994). The Cambridge companion to Foucault. Cambridge: Cambridge University Press.

Habermas, J. (1986). Taking aim at the heart of the present. In D. Couzens Hoy (Ed.), Foucault: A critical reader (pp. 103-108). Oxford: Blackwell Publishers.

Habermas, J. (1989). The structural transformation of the public sphere: An inquiry into a category of Bourgeois Society (T. Burger \& F. Lawrence, Trans.). Cambridge: Polity Press.

Habermas, J. (1990). Moral consciousness and communicative action (C. Lenhardt \& S. Weber Nicholsen, Trans.). Cambridge: Polity Press.

Habermas, J. (1995). Reconciliation through the public use of reason: Remarks on John Rawls's Political Liberalism. The Journal of Philosophy, 92(3), 109-131.

Habermas, J. (1996). Between facts and norms: Contributions to a discourse theory of law and democracy (W. Rehg, Trans.). Cambridge: The MIT Press.

Heath, J. (2001). Communicative action and rational choice. Cambridge: The MIT Press.

Heath, J., \& Norman, W. (2004). Stakeholder theory, corporate governance and public management: What can the history of state-run enterprises teach us in the post-Enron era? Journal of Business Ethics, 53(3), 247-265.

Jamali, D. (2010). MNCs and international accountability standards through an institutional lens: Evidence of symbolic conformity or decoupling. Journal of Business Ethics, 95(4), 617-640.

Kostova, T., Roth, K., \& Dacin, M. T. (2008). Institutional theory in the study of multinational corporations: A critique and new directions. Academy of Management Review, 33(4), 994-1006. 
Kuhn, T. S. (1996). The structure of scientific revolutions (3rd ed.). Chicago: University of Chicago Press.

Laclau, E., \& C. Mouffe. (1985). Hegemony and socialist strategy: Towards a radical democratic politics (W. Moore \& P. Cammack, Trans.). Verso: London.

Levy, D. L. (2008). Political contestation in global production networks. Academy of Management Review, 33(4), 943-963.

Levy, D., \& Scully, M. (2007). The institutional entrepreneur as modern Prince: The strategic face of power in contested fields. Organization Studies, 28(7), 971-991.

Luhman, N. (1993). The code of the moral. Cardozo Law Review, 14(3-4), 995-1009.

Melucci, A. (1996). Challenging codes: Collective action in the information age. Cambridge: Cambridge University Press.

Meyer, J. W., \& Rowan, B. (1977). Institutionalized organizations: Formal structure as myth and ceremony. The American Journal of Sociology, 83(2), 340-363.

Mill, J. S. (1859). On liberty. In S. Collini (Ed.), On liberty: With, the subjection of women; and chapters on socialism (pp. 1-115). Cambridge: Cambridge University Press.

Moravcsik, A. (2000). The origins of human rights regimes: Democratic deliberation in postwar Europe. International Organization, 54(2), 217-252.

Naess, A. (1973). The shallow and the deep, long-range ecology movement. A summary. Inquiry, 16(1), 95-100.

Naidoo, K. (2009, November 15). Introducing Kumi Naidoo as New Greenpeace International Executive Director. Retrieved December 21, 2012, from http://www.youtube.com/watch?v=5_VYX8hTOCI.

O'Neill, O. (1989). Constructions of reason: Explorations of Kant's Practical Philosophy. Cambridge: Cambridge University Press.

Oliver, C. (1991). Strategic responses to institutional processes. Academy of Management Review, 16(1), 145-179.

PETA (People for the Ethical Treatment of Animals). Retrieved December 21, 2012, from http://www.peta.org.

Prasad, P., \& Elmes, M. (2005). In the name of the practical: Unearthing the hegemony of pragmatics in the discourse of environmental management. Journal of Management Studies, 42(4), 845-867.

Rawls, J. (1999). The law of peoples, with "the idea of public reason revisited". Cambridge: Harvard University Press.
Rescher, N. (1993). Pluralism: Against the demand for consensus. Oxford: Clarendon Press.

Scherer, A. G., \& Palazzo, G. (2007). Toward a political conception of corporate social responsibility-Business and society seen from a Habermasian perspective. Academy of Management Review, 32(4), 1096-1120.

Scherer, A. G., \& Palazzo, G. (2011). The new political role of business in a globalized world: A review of a new perspective on CSR and its implications for the firm, governance and democracy. Journal of Management Studies, 48(4), 899-931.

Sealy, L., \& Worthington, S. (2008). Cases and material in company law (8th ed.). Oxford: Oxford University Press.

Shanahan, S., \& Khagram, S. (2006). Dynamics of corporate responsibility. In G. Drori, J. Meyer, \& H. Hwang (Eds.), Globalization and organization: World society and organizational change (pp. 196-224). Oxford: Oxford University Press.

Shell. Retrieved December 21, 2012, from http://www.shell.com.

Shell. (2012). Building an energy future: Annual report 2011. Retrieved December 21, 2012, from http://www.shell.com/ home/content/investor/financial_information/annual_reports_ and_publications/.

Shell Dialogues. Retrieved December 21, 2012, from http://www. shelldialogues.com.

Spence, C. (2009). Social accounting's emancipatory potential: A Gramscian critique. Critical Perspectives on Accounting, 20(2), 205-227.

Suchman, M. C. (1995). Managing legitimacy: Strategic and institutional approaches. Academy of Management Review, 20(3), 571-610.

Tsoukas, H. (1999). David and Goliath in the risk society: Making sense of the conflict between Shell and Greenpeace in the North Sea. Organization, 6(3), 499-528.

Willke, H., \& Willke, G. (2008). Corporate moral legitimacy and the legitimacy of morals. Journal of Business Ethics, 81(1), 27-38.

WWF (World Wildlife Fund). Retrieved December 21, 2012, from http://wwf.panda.org/.

Ziarek, E. P. (2001). An ethics of dissensus: Postmodernity, feminism, and the politics of radical democracy. Stanford: Stanford University Press. 